\title{
Water and temperature dynamics of Aquands under different uses in southern Chile
}

\author{
Dorota Dec ${ }^{1,2}$, Felipe Zúniga ${ }^{2,3}$, Oscar Thiers ${ }^{2,4}$, Leandro Paulino ${ }^{2,5}$, Susana Valle ${ }^{1,2}$, Valeria \\ Villagra $^{1}$, Ivo Tadich ${ }^{6}$, Rainer Horn ${ }^{2,7}$ and José Dörner ${ }^{1,2 *}$
}

${ }^{1}$ Instituto de Ingeniería Agraria y Suelos, Facultad de Ciencias Agrarias, Universidad Austral de Chile, Campus Isla Teja, Valdivia, Chile. ${ }^{2}$ Centro de Investigación en Suelos Volcánicos, Universidad Austral de Chile, Campus Isla Teja, Valdivia, Chile. ${ }^{3}$ Doctorado en Ciencias Agrarias, Escuela de Graduados, Facultad de Ciencias Agrarias, Universidad Austral de Chile, Campus Isla Teja, Valdivia, Chile. ${ }^{4}$ Instituto de Bosques y Sociedad, Facultad de Ciencias Forestales y Recursos Naturales, Universidad Austral de Chile, Campus Isla Teja, Valdivia, Chile. ${ }^{5}$ Departamento de Suelos y Recursos Naturales, Facultad de Agronomía, Universidad de Concepción, Campus Chillán, Chillán, Chile. ${ }^{6}$ Magister en Ciencias Mención Recursos Hidricos, Facultad de Ciencias, Universidad Australde Chile, Campus Isla Teja, Valdivia, Chile. ${ }^{7}$ InstituteforPlantNutritionand SoilScience, ChristianAlbrechts University zu Kiel, Hermann Rodewaldstr. 2, 24118 Kiel, Germany.*Correspondingauthor: josedorner@uach.cl

\begin{abstract}
Aquands are soils derived from holocenic volcanic ashes located in southern Chile. Due to the presence of very high levels of organic matter (30\%), these soils present a high total porosity ( $80 \%$ ) but at the same time, a limited water storage capacity due to their shallow soil depths. The aim of this work was to analyze the influence of land use change of a Duric Histic Placaquand (Ñadi) soil on soil physical properties and their consequences on water and temperature dynamics. The volumetric water content $\left(\theta_{\text {Field }}\right)$ and soil temperature $(T)$ were registered at different depths in a Ñadi soil under a secondary native forest (sNF) and naturalized grassland (NG). Undisturbed soil samples were collected to analyze the water retention curve, saturated (Ks) and unsaturated (Ku) hydraulic conductivity and water repellency. The dynamics of rainfall and water table depth (WT) were registered using a rain gauge and groundwater wells. The land use change of a Nadi soil from sNF to NG induced soil structural changes in the first $15 \mathrm{~cm}$ of soil reducing the amount of macropores under NG and affecting the hydraulic conductivity function as well as $\theta_{\text {Field }}$ and $\mathrm{T}$ dynamics, i.e. while the WT in winter reached the soil surface in the NG, under SNF the air-filled pores were still present. Similarly, the T gradients increased as $\Theta_{\text {Field }}$ decreased, being more intensive under NG. A nonhomogeneous soil wetting and water infiltration was assessed, which can be related to an increased spatial water repellency, soil hydraulic properties and rainfalls.
\end{abstract}

Keywords: Andisol, Ñadi, vadose zone, soil use change, water repellency, thermal properties 


\section{Introduction}

Land use change from native forest to arable soils probably started when humans began agricultural production. In Chile, Fuente and Hajek (1979) conducted the first investigations about anthropogenic landscape changes. Subsequently, Wilson et al., (2005) investigated the causes of loss and fragmentation of native forests in central and southern Chile. They concluded that the main reasons for these transformations were: i) adaptation to agriculture and ii) expansion of forest plantations as a consequence of state policy (subsidy) (Donoso and Lara 1996). All these anthropogenic activities were conducted on volcanic ash soils, which represent less than $1 \%$ of the soils in the world, but $60 \%$ of arable soils in Chile (Besoain and Sepúlveda, 1985).

The influence of the land use change on soil physical properties and pore functions has been described for many soils (e.g. Indorante et al., 2013) and is well known for Typic Hapludands (locally called Trumaos) in southern Chile (Ellies et al., 1996; Dörner et al., 2009, 2010, 2015). However, little research has been carried out on Ñadi (Aquands) soils (Ellies, 2001; Thiers et al., 2007; Dörner et al., 2016). These soils are located between $38^{\circ} 30^{\prime}-43^{\circ} 00^{\prime} \mathrm{S}$, cover an area of about 475.000 hectares and represent $9 \%$ of the Andisols in the country (CIREN, 2003). The fragility of Nadi soils is related to their shallow soil depth, which can range between $20 \mathrm{~cm}$ and $90 \mathrm{~cm}$ (CIREN, 2003). The latter is relevant, since one of the properties affected directly by the land use and cover changes is the soil depth, which at the same time influences other soil properties and processes (e.g. water holding capacity, soil temperature and water dynamics).

Soil depth is one of the most relevant soil physical properties, because it defines the soil storage capacity (e.g. for organic carbon, water and air), as well as being the deciding factor for possible cultivation e.g. considering the length of crop roots and water storage capacity. Soil depth affects the amount and variety of subsurface microbes, which play an important role in soil formation, ecosystem biogeochemistry, contaminant degradation, and the maintenance of groundwater quality (Richter and Markewitz, 1995, Cuevas et al., 2014). On the other hand, soil depth, combined with soil porosity, defines the water storage capacity (e.g. Dörner et al., 2016), which is highly relevant if we consider water demand by plants, particularly in the scenario of an increasing human population and hence, increasing demands for food, under a decreasing precipitation trend along the southern Pacific coast of South America (IPCC, 2013).

The increasing demand for food and energy necessitates the search for new soil types, which could potentially be useful for agriculture, or for improving soils, which have limitations. The latter is the case of Ñadi soils, which, due to their shallow depth affected from the presence of a placic horizon (Luzio, 2010) which cause water logging during winter and intensive drying during summer (Thiers et al., 2007; Dörner et al., 2016). As a result of a Chilean government policy and subsidies provided for their habilitation for agricultural use, these soils have been subjected to an intense change in land use and vegetation cover (Gerding et al., 2014). However, questions related to their potential use in agricultural or forestry activities or the consequences of the land use and cover changes on the ecosystem services of these soils have not been sufficiently studied.

Therefore, the aim of this work was to analyze the influence of land use change in a Nadi soil (Duric Histic Placaquands) on soil physical properties and their consequences on water and temperature dynamics in space and time. 


\section{Material and Methods}

\subsection{Soil and land use history}

The experimental field is located in southern Chile, $17 \mathrm{~km}$ northwest of Puerto Montt ( $41^{\circ} 26^{\prime}$ 72 ” S, 73 7' 70” W) (Figure 1). This area (10.000 $\mathrm{m}^{2}$ ) consists of two land uses: Secondary Native Forest (sNF) and Naturalized Grassland (two sites: NG1 and NG2). General characteristics of this zone are: the slope $<1 \%$, elevation of $73 \mathrm{~m}$ a.s.l., and humid temperate climate with maritime influence (Novoa and Villaseca, 1989). The amount of rainfall varies between 1.783 and $2.021 \mathrm{~mm}$ year $^{-1}$ (with $261 \mathrm{~mm}$ in July) and the mean annual temperature is $10.7^{\circ} \mathrm{C}$ (with $4.1{ }^{\circ} \mathrm{C}$ in July).

The Duric Histic Placaquands (Nadi, Alerce Series) is derived from volcanic ash over glaciofluvial deposit, and corresponds to the outwash plain of the piedmont glaciers from the Andes. For a general soil description a gouge auger (Eijkelkamp; length: 100 $\mathrm{cm}$, diameter: $3 \mathrm{~cm}$ ) was used. Based on information obtained, sites with similar depths (under NFs and NG) were selected and the morphological characterisation was made (described in Dörner et al., 2016). In general, soil texture changed from loam in the first $20 \mathrm{~cm}$ of soil to clay in the deeper soil horizons and a decrease of soil organic carbon with increasing soil depth was observed in both profiles: sNF $(26.2 \%$ to $10.6 \%)$ and NG $(25.4 \%$ to $6.9 \%)$. Originally, the investigated area was under secondary native forest, however as a consequence of fire in 1980 the naturalized grassland was formed. After this event, the soil surface was cleaned from the remaining roots and wood, and then the naturalized grassland was established. No improvement management practices or grazing management (free grazing by sheep and cows) were conducted. Grazing sheep and cows also have free entrance to the
SNF, which in this case depends on the tree and bush density. The soil depth decreased as a consequence of the land use change as presented in Haller et al., (2015) and Dörner et al., (2016) and can clearly be seen in contour maps of spatial distribution of soil depth (Figure 1), prepared using the geostatistical software GS + version 9.0 (Dörner et al., 2016). These maps show that the deepest soil profile, with an average of $69.9 \mathrm{~cm}$, was observed under sNF (max: 91.5; $\min : 30 \mathrm{~cm}$ ) (Figure 1). Under the naturalized grassland (NG) some differences were observed, where higher values were assessed in NG2 with an average of $59.1 \mathrm{~cm}$ (max: 76; $\min : 41 \mathrm{~cm}$ ) compared to $42.7 \mathrm{~cm}(\max : 54$; $\min : 30 \mathrm{~cm}$ ) in NG1.

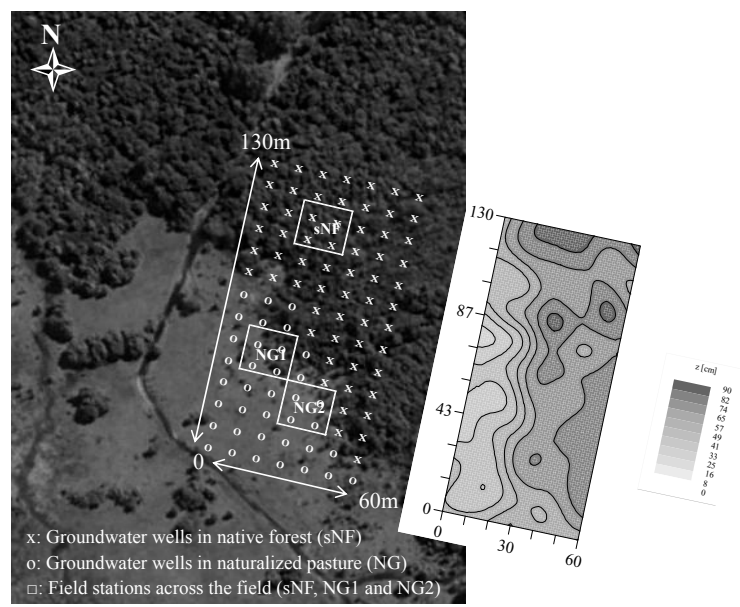

Figure 1. Spatial arrangement of groundwater wells and field stations across the field. sNF corresponds to a secondary native forest; NG a naturalized grassland. Squares indicate the meteorological station location. The map on the right indicates the spatial variability of the soil depth registered in the field after Dörner et al., (2016).

\subsection{Field analyses and soil sampling collection}

The spatiotemporal changes of the water table depth were determined at defined grid points. This grid consisted of seven rows divided into 14 points separated by a distance of $10 \times 10 \mathrm{~m}$ (Figure 1). The total measured consisted of 
98 points and included $7800 \mathrm{~m}^{2}$. At each point, the effective depth was determined with a gouge auger (Eijkelkamp) (Dörner et al., 2016). Thereafter, in the same place a groundwater well $(\mathrm{h}=90 \mathrm{~cm}$, $\phi=3 \mathrm{~cm}$ ) was installed to register the dynamics of the water table depth (WT). The latter was measured periodically with a tape connected to a Digital Multimeter (DT830D, Eastern, China).

Meteorological stations were installed under the two land uses (secondary native forest [sNF] and naturalized grasslands [NG1, NG2]) to determine the dynamics of precipitations in the field as well as temperature and water content in soil profiles (Figure 1). Precipitations were registered with ECRN Rain Gauge (Decagon Devices, Pullman, Washington, USA), temperature and water content with 5 TM (Decagon Devices, USA) sensors installed at depths of 5,10 and $40 \mathrm{~cm}(\mathrm{n}=2)$. Data were registered every 10 minutes (Em50, Decagon Devices, USA), and are presented as daily mean data for June 2013 to September 2015.

Disturbed (in plastic bags) and undisturbed (in stainless steel cylinders) soil samples were taken from 5, 15, 30 and $50 \mathrm{~cm}$ depths under sNF and NG (NG under $50 \mathrm{~cm}$ was not sampled owing to water saturation). Undisturbed soil samples were used to determine the water retention curve, saturated and unsaturated hydraulic conductivity and water repellency index while particle density and contact angle were determined from disturbed samples.

\subsection{Laboratory analyses}

In order to study the soil hydraulic properties, the water retention curve and the saturated hydraulic conductivity (Ks) were measured (stainless steel cylinders, $\mathrm{v}=230 \mathrm{~cm}^{3} ; \mathrm{h}=5.60 \mathrm{~cm}, \varnothing=7.20 \mathrm{~cm}$ ). To determine the soil water retention, the samples $(\mathrm{n}=7$ for each depth) were first carefully saturated from beneath. When saturation was reached, the samples were first weighed, then equilibrated at matric potential values of $-10,-20,-30,-60$ (in sand tables), $-150,-330,-500 \mathrm{hPa}$ (in pressure chambers) and weighed at each suction with an electronic balance (Precisa, $0.01 \mathrm{~g}$ accuracy, Switzerland). To define the volume of fine pores, samples were collected in cylinders of $20 \mathrm{~cm}^{3}$ and were then equilibrated at a matric potential of $-15430 \mathrm{hPa}$. The volumes of wide coarse pores (wCP, $\varnothing>50 \mu \mathrm{m}$ ) and plant available water (PAW) were calculated using the volumetric water contents $(\Theta)$ measured at different matric potentials in samples used for the water retention curves (Dörner $e t$ al., 2016). The water retention curves are presented as the relationship between volumetric water content (corrected depending on soil shrinkage according to Dörner et al., 2010 ) and $\mathrm{pF}$ value (log matric potential in $\mathrm{hPa}$ ).

For the Ks analysis, the undisturbed soil samples $(n=10$ for each depth) were placed inside the water permeameter (Eijkelkamp, model 09.02.01.25, The Netherlands) and saturated by means of capillary rise from beneath for 48 hours. The Ks measurements were conducted under stationary conditions. Thereafter, the samples were taken out from the water permeameter and saturated again to measure the water repellency index (R) (according to Hallett et al., (2004)), at different water contents equilibrated at $-60 \mathrm{hPa}$ of matric potential, after 2 and 7 days in controlled air temperature $\left(20^{\circ} \mathrm{C}\right)$, and after drying in an oven at $105^{\circ} \mathrm{C}$ for 24 hours. The unsaturated hydraulic conductivity $(\mathrm{Ku})$ was determined using the evaporation method, using HYdraulic PROPerty analyser (HYPROP), where $\mathrm{Ku}$ is calculated according to the Darcy Buckingham law, as follows:

$$
\mathrm{K}_{\mathrm{u} \psi \text { mean }}=\frac{\Delta V}{2 \mathrm{~A} \Delta t i m}
$$

where: $\psi_{\text {mean }}$ (for k) is the mean matric potential averaged across the tensiometer at position $\mathrm{z}_{1}$ (upper) and $\mathrm{z}_{2}$ (lower part of the cylinder) and averaged across the time interval $\Delta \mathrm{t} ; \Delta \mathrm{V}$ is the total evaporated water volume of the complete sample (difference of sample mass: $\Delta \mathrm{m}$, in the interval), $\mathrm{A}$ is the cross-sectional area of the sample and $\mathrm{i}_{\mathrm{m}}$ is the mean hydraulic gradient in 
the time interval. Details of this methodology are described in Schindler et al., (2010). Due to the complex nature of the inter- and intra-aggregate porosity of Andisols (e.g. Dörner et al., 2016), the measured hydraulic conductivity values were adjusted to the dual porosity model using RETC v. 6.02 (van Genuchten et al., 2009).

The disturbed soil samples were air-dried and then sieved to $2 \mathrm{~mm}$. The particle density was measured using the pycnometer method (Klute, 1986). To determine the contact angle, the sieved soil was spread as a monogranular layer of microaggregates on clean glass slides. The aggregates were attached to the slide with adhesive double-sided tape. On this microaggregate layer, 3 drops $\left(0.04 \mathrm{~cm}^{3}\right.$ of saturated $\left.\mathrm{KCl}\right)$ of water solution were scattered with a syringe and the contact angle measured with a goniometer located in the ocular of a microscope with a horizontal vision field. The contact angle corresponds to a tangential line visible to the eye, whose origin is the intersection of the water-air-solid phase, which is projected as a tangent to the surface at the maximum curvature of the drop (Ellies et al., 2003). The wetting capacity of the soil is high when the drop spreads, and low when it maintains its spherical form. The normality of data was evaluated with ShapiroWilk test $(p<0.05)$. According to its distribution, the hydraulic conductivity values were log-transformed. Mean values of the studied physical properties with corresponding standard errors are presented.

\section{Results}

\subsection{Impact of the land use change on soil hydraulic} properties

Selected hydraulic properties of the soil are presented in Table 1. Under sNF, the particle density (Dp) did not change until the depth reached $15 \mathrm{~cm}$ with $1.0 \mathrm{~g} \mathrm{~cm}^{-3}$, but then increased to $2.3 \mathrm{~g} \mathrm{~cm}^{-3}$ in the last horizon. On the other hand, a more gentle increase in $\mathrm{Dp}$ with depth was noticed in NG. The same was observed for bulk density $(\mathrm{Db})$ for the two land uses (except NG $-15 \mathrm{~cm})$. These changes in both Dp and Db imply that the total porosity of the soil ranged between $83.9 \%$ (5 cm depth in sNF) and 67.6\% (5 cm depth NG).

Table 1. Selected physical properties of the studied soils under secondary native forest (sNF) and naturalized grassland (NG). Mean values \pm 1 standard error are presented.

\begin{tabular}{|c|c|c|c|c|c|c|c|c|}
\hline \multirow[t]{2}{*}{ Land use } & Depth & Dp & $\mathrm{Db}$ & TP & wCP & PAW & $\mathrm{K}_{\mathrm{s}}$ & $\theta$ \\
\hline & {$[\mathrm{cm}]$} & {$\left[\mathrm{g} \mathrm{cm}^{-3}\right]$} & {$\left[\mathrm{g} \mathrm{cm}^{-3}\right]$} & [Vol. \%] & [Vol. \%] & [Vol. \%] & {$\left[\log \mathrm{cm}\right.$ day $\left.^{-1}\right]$} & {$\left[{ }^{\circ}\right]$} \\
\hline \multirow[t]{4}{*}{ sNF } & 5 & $1.08 \pm 0.05$ & $0.17 \pm 0.02$ & $83.9 \pm 1.7$ & $19.1 \pm 1.9$ & $41.9 \pm 1.4$ & $3.12 \pm 0.35$ & $117 \pm 1$ \\
\hline & 15 & $1.07 \pm 0.01$ & $0.28 \pm 0.01$ & $73.8 \pm 1.1$ & $13.2 \pm 2.4$ & $33.6 \pm 1.9$ & $3.33 \pm 0.20$ & $116 \pm 1$ \\
\hline & 30 & $2.30 \pm 0.05$ & $0.40 \pm 0.04$ & $82.3 \pm 1.9$ & $4.2 \pm 1.3$ & $51.1 \pm 1.3$ & $2.20 \pm 0.30$ & $85 \pm 7$ \\
\hline & 50 & $2.30 \pm 0.05$ & $0.61 \pm 0.03$ & $73.4 \pm 1.1$ & $3.4 \pm 0.9$ & $40.2 \pm 2.1$ & n.d. & n.d. \\
\hline \multirow[t]{3}{*}{ NG } & 5 & $1.39 \pm 0.03$ & $0.45 \pm 0.01$ & $67.6 \pm 1.1$ & $9.2 \pm 1.0$ & $35.9 \pm 1.3$ & $2.71 \pm 0.19$ & $107 \pm 1$ \\
\hline & 15 & $1.78 \pm 0.04$ & $0.39 \pm 0.01$ & $78.0 \pm 0.5$ & $15.0 \pm 1.9$ & $37.7 \pm 2.3$ & $2.88 \pm 0.10$ & $113 \pm 1$ \\
\hline & 30 & $2.31 \pm 0.13$ & $0.65 \pm 0.04$ & $71.8 \pm 1.9$ & $4.9 \pm 1.2$ & $37.5 \pm 1.4$ & $2.54 \pm 0.20$ & $97 \pm 2$ \\
\hline
\end{tabular}

sNF: secondary native forest, NG: naturalized grassland, Dp: particle density, Db: bulk density, TP: total porosity, wCP: air capacity, PAW: plant available water, Ks: saturated hydraulic conductivity, $\theta$ : Contact angle. n.d.: not determined. 
The volumetric water contents at saturation $(0 \mathrm{hPa})$ were higher and varied more under sNF, compared to the NG plot (Figure 2). At pF 4.2 (permanent wilting point) the values increased with depth under both SNF and NG. Despite the same water content at saturation, the WRC's of sNF ( 5 with 30 , and 15 with $50 \mathrm{~cm}$ ) presented a particular behavior with increasing $\mathrm{pF}$ value (decreasing matric potential), showing some characteristics and similar shape with depth increase. For the first two sampling horizons, the WRC's showed three inflection points (at $\mathrm{pF}$ values of $1.3 ; 1.78$ and 2.52 ), whereas at 30 and $50 \mathrm{~cm}$ depths two inflection points were observed (at $\mathrm{pF}$ values of 1.78 and 2.7). Differences in volumetric water contents at specific $\mathrm{pF}$ values were observed, which were higher between

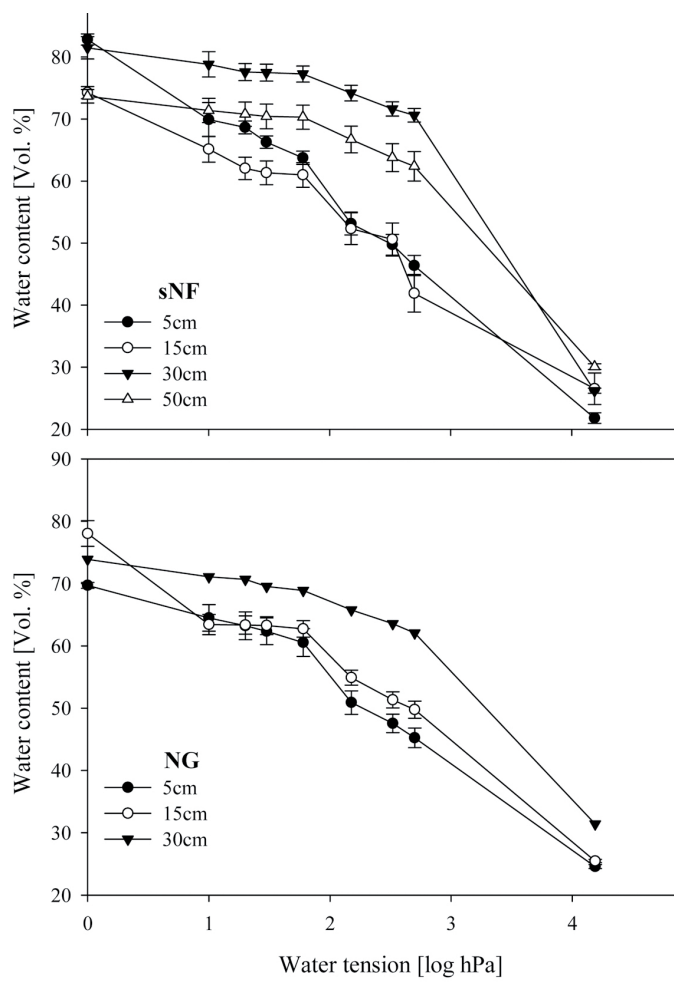

Figure 2. Water retention curves as a function of land use (sNF and NG) and soil depth. Mean values \pm 1 standard error is presented $(n=7)$.
30 and $50 \mathrm{~cm}$ (almost $10 \%$ between saturation and $\mathrm{pF}$ $2.78)$ than between 5 and $15 \mathrm{~cm}(6 \%$ between saturation and $\mathrm{pF}$ 1.5). WRC's from NG presented a similar development as observed in SNF; however, the water content at saturation was higher at $15 \mathrm{~cm}$ than at $5 \mathrm{~cm}$ depth. The changes in WRC are reflected in the amount of wide coarse pores (wCP) and plant available water (PAW). Regarding wCP, the greatest difference was observed at $5 \mathrm{~cm}$ depth (19 and 9 Vol.\% for sNF and NG). With depth increase, more wCP were determined for grassland, however, the difference between land uses was much smaller. The plant available water was higher in sNF compared to NG reaching clear maximum values at $30 \mathrm{~cm}$ depth in $\mathrm{SNF}$ and minimum values at $15 \mathrm{~cm}$ and $5 \mathrm{~cm}$ depths for $\mathrm{sNF}$ and NG, respectively.

The hydraulic conductivity as a function of matric potential ( $\mathrm{pF}$ value) is presented in Figure 3. The saturated hydraulic conductivity (Ks) is also presented in Table 1. Ks values at 5 and $15 \mathrm{~cm}$ depth were in sNF higher than in NG, whereas they reached comparable values at $30 \mathrm{~cm}$ depth. Thereafter, as soon as the amount of water-filled pores decreased, the decrease in $\mathrm{Ku}$-values seemed to be independent of the land use and depth (e.g. in sNF at $5 \mathrm{~cm}$ depth $\mathrm{Ks}$ changed to $\mathrm{Ku}$ from 3.12 to $-1.2 \log \mathrm{cm}_{\text {day }}{ }^{-1}$ ). Since we could not determine values of $\mathrm{Ku}$ close to saturated conditions, the measured values were adjusted to the dual porosity model with high correlation values $\left(\mathrm{R}^{2}=0.99\right)$ with the exception of the values measured at $15 \mathrm{~cm}$ depth in $\mathrm{sNF}$. When comparing $\mathrm{Ku}$-values between land uses at $5 \mathrm{~cm}$ depth, the measured unsaturated hydraulic conductivity at comparable pF-values (near 2.3) in sNF (ranged between -2.28 and $-2.54 \log \mathrm{cm}^{-1 a y}{ }^{-1}$ ) was lower than those registered in NG (ranged between -1.36 and $\left.-1.45 \log \mathrm{cm} \mathrm{day}^{-1}\right)$. A similar behavior was observed at $15 \mathrm{~cm}$ depth. 

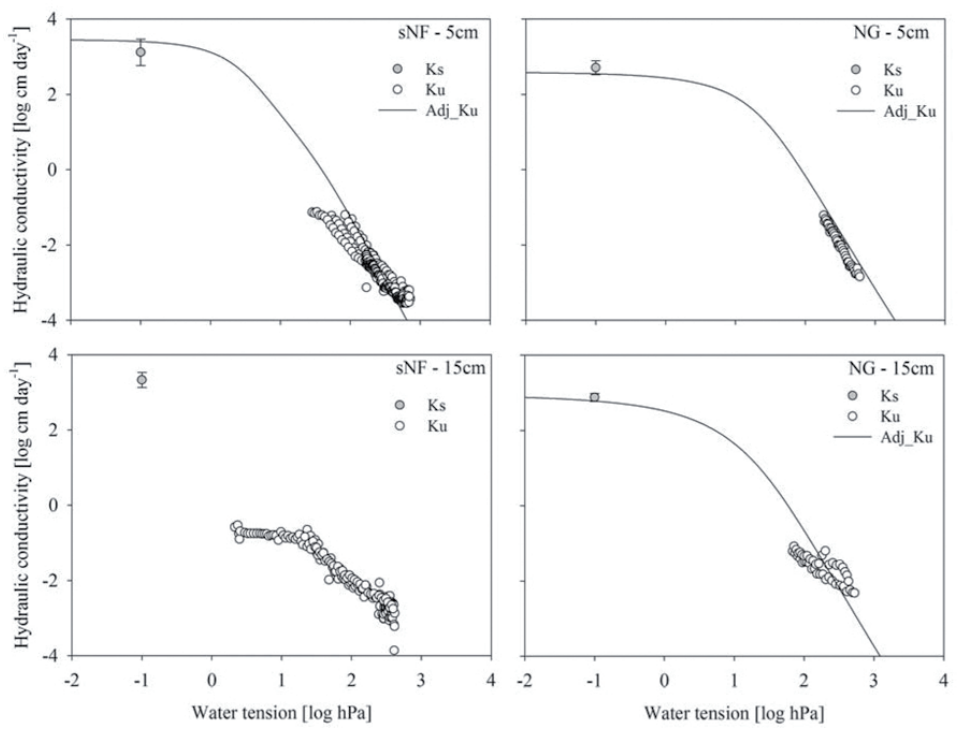

Figure 3. Hydraulic conductivity as a function of water tension for different land uses considering two soil depths. $\mathrm{Ks}=$ saturated hydraulic conductivity (mean value \pm 1 standard error), $\mathrm{Ku}=$ unsaturated hydraulic conductivity (measured values for 3 replicates, all data is presented).

The soil hydrophobicity was evaluated using the contact angle (Table 1) and the water repellency index ( $\mathrm{R}$ in Figure 4). The contact angle ( $\theta$ ) was higher in SNF compared to NG and decreased with soil depth. On the other hand, $\mathrm{R}$ increased with decreasing volumetric water content reaching values between 1.0 and 5.4. At a matric potential of $-6 \mathrm{kPa}$, $\mathrm{R}$-values ranged from 1.5 to 1.0 and no major differences between land uses and soil depth were observed. For the dry soil, and considering land uses and soil depths, higher R-values were observed at a depth of $5 \mathrm{~cm}$ than at $15 \mathrm{~cm}$, with the highest value of 5.4 for SNF.

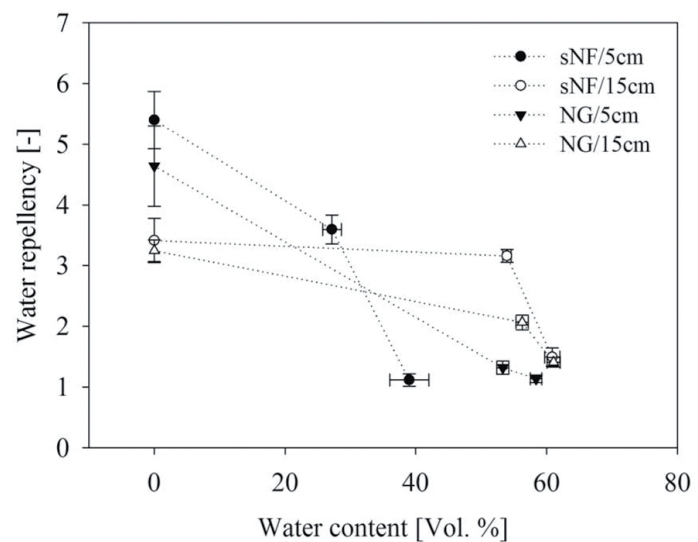

Figure 4. Water repellency index as a function of land use, soil depth and soil water content. Mean values \pm 1 standard error $(\mathrm{n}=10)$. 


\subsection{Temporal changes in water and temperature $d y$ -} namics

In order to characterize the influence of land use and cover changes on water content dynamics, rainfalls were registered under sNF and NG, showing, as expected, higher values under NG during the investigated period (Figure 5). Rainfalls increased gradually from June 2013 and then decreased at the end of that year, reaching the highest registered values at $01.06 .2014(27 \mathrm{~mm}$ for $\mathrm{sNF}$ and $89 \mathrm{~mm}$ for NG, respectively). Thereafter, rainfalls gradually decreased and between 01.12.2014 and 31.03.2015 only $139 \mathrm{~mm}$ of precipitations were measured. Due to the rainfall interception under forest, the fluctuations and values in SNF were much smaller compared to NG. The cumulative rainfall, during the studied period, were: 297, 622, $446 \mathrm{~mm}$ and 434, 1885, 1415 $\mathrm{mm}$ for forest and grassland in years 2013, 2014 and 2015, respectively. Maximal intensity was reached between May and August 2014 with 264 for sNF and $870 \mathrm{~mm}$ for NG.
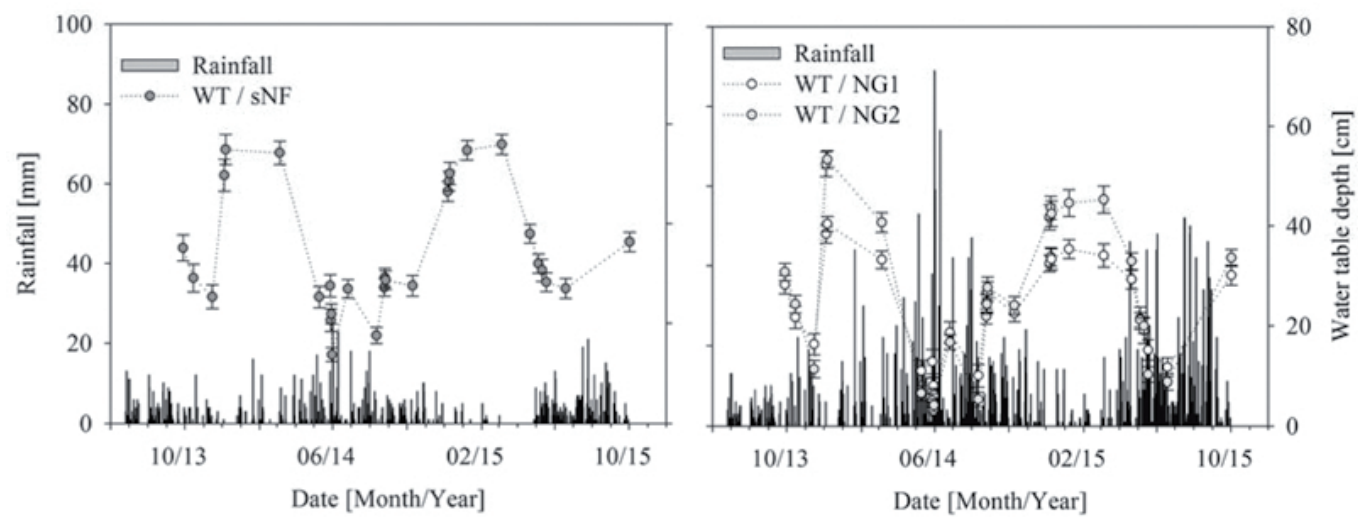

Figure 5. Dynamics of rainfall and water table depth for the studied land uses (sNF, NG1, NG2).

The water table depth (WT) showed a dynamic behavior during the year related to temporal changes in rainfalls (Figure 5). While the lowest values were registered in June 2014, the opposite was assessed during March 2015 (sNF > NG2 > NG1). In June 2014, WT reached 22, 8 and $3 \mathrm{~cm}$ in $\mathrm{sNF}, \mathrm{NG} 2$ and NG1, respectively. When considering the whole period, WT on average was $\mathrm{SNF}(34 \mathrm{~cm})>\mathrm{NG} 2(25 \mathrm{~cm})>\mathrm{NG} 1$ $(23 \mathrm{~cm})$. The field water content $\left(\theta_{\text {Field }}\right)$ and temperature $(\mathrm{T})$ dynamics are presented in Figure $6 . \theta_{\text {Field }}$ presented minimum and maximum values of $5 \%(5 \mathrm{~cm}$ depth in sNF) and almost $80 \%$ (40 cm depth in SNF). While both grasslands presented higher $\theta_{\text {Field }}$ values at $5 \mathrm{~cm}$ depth, the opposite was observed for deeper horizons. For all sites, $\theta_{\text {Field }}$ increased with increasing soil depth and the most dynamic changes were observed at $5 \mathrm{~cm}$ depth compared to 15 and $40 \mathrm{~cm}$ depths. The latter is particularly true in June 2014, when between 31.05 and $02.06 \theta_{\text {Field }}$ changed from $34 \%$ to completely saturated conditions $(77 \%)$ in sNF. On the other hand, between December 2014 and March 2015 a very intensive drying cycle was registered which implies a reduction of $\theta_{\text {Field }}$ in all studied soil depths. Thereafter, an increase in $\theta_{\text {Field }}$ values was observed with the most dynamic changes in the grasslands compared to sNF. 

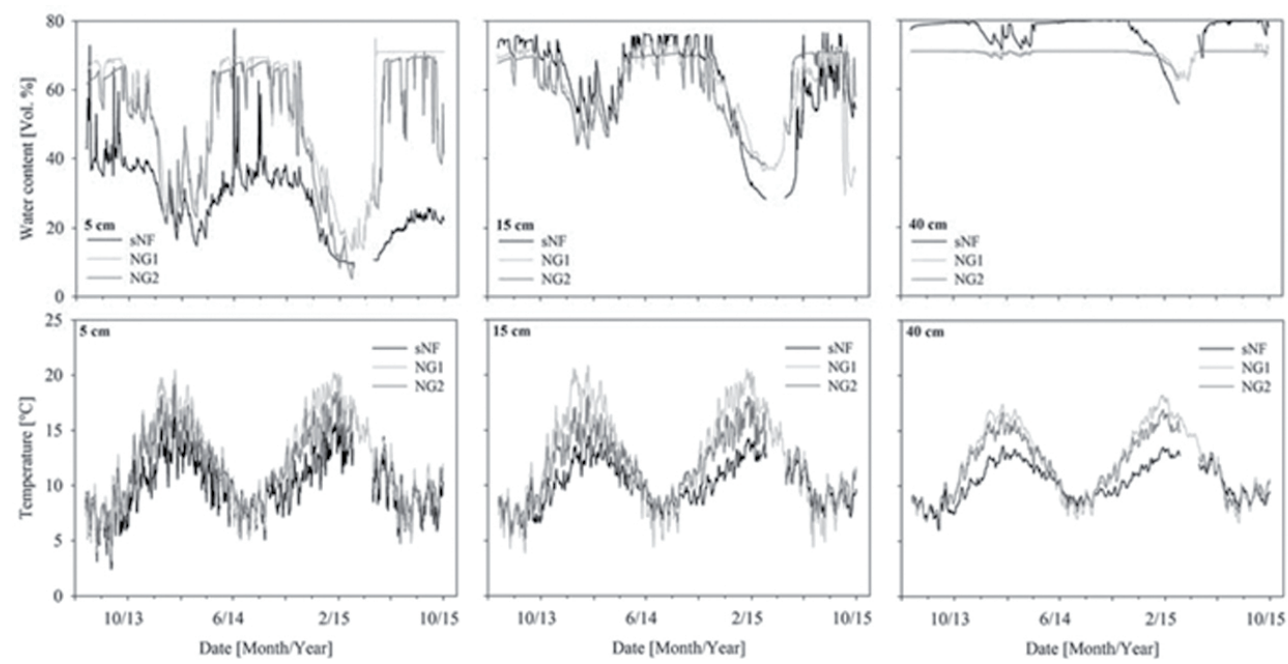

Figure 6. Dynamics of soil water content and temperature at investigated depths $(5,15,40 \mathrm{~cm})$ and land uses (sNF, NG1, NG2).

As a response to these natural non-uniform variations in the amount of precipitation, changes in the water content $\left(\theta_{\text {Field }}\right)$ in the soil profile was observed (Figure 5,6$)$. These changes are noticed very quickly in the soil profile, although how fast the response is depends on the direction of water flow (wetting-drying or drying-wetting cycle). For example, between December and March of both 2014/15 and 2015/16 a clear decrease of $\Theta$ was observed, which was more intense in the second period compared to 2014/15. After this period a wetting cycle occurred (Figure 7), which was, compared to the drying cycle, not homogeneous for the whole soil profile, i.e. the re-saturation of 5 and 15 $\mathrm{cm}$ depths was delayed, especially in sNF. The latter was observed in the field during soil sampling conducted on 18.05.2015. While the soil was almost completely saturated at $15 / 20 \mathrm{~cm}$ depth, it was dry at $5 \mathrm{~cm}$ depth under sNF as well as in some areas under NG.
The soil temperature ( $\mathrm{T}$ ) presented daily and seasonal patterns (Figure 6). At $5 \mathrm{~cm}$ depth, for the whole period, $\mathrm{T}$ in grasslands were higher (maximum daily values reached $20^{\circ} \mathrm{C}$ ) than in sNF (maximum daily values reached $16^{\circ} \mathrm{C}$ ) with mean values of 10,12 and $12{ }^{\circ} \mathrm{C}$ for sNF, NG1 and NG2, respectively. The temperature decreased with increasing soil depth. While mean values in 5 and $40 \mathrm{~cm}$ depths were almost the same during the studied period, the maximum values were: $\mathrm{NG} 1\left(20.5^{\circ} \mathrm{C}\right)>\mathrm{NG} 2$ $\left(19.2^{\circ} \mathrm{C}\right)>\operatorname{sNF}\left(16.2^{\circ} \mathrm{C}\right)$ at $5 \mathrm{~cm}$ depth and NG1 $\left(18.2^{\circ} \mathrm{C}\right)>\operatorname{NG} 2\left(16.9^{\circ} \mathrm{C}\right)>\operatorname{sNF}\left(13.6^{\circ} \mathrm{C}\right)$ at $40 \mathrm{~cm}$ depth as well as the minimum values were: NG2 $\left(4.4^{\circ} \mathrm{C}\right)>\operatorname{NG1}\left(3.3^{\circ} \mathrm{C}\right)>\operatorname{sNF}\left(2.4^{\circ} \mathrm{C}\right)$ and $\mathrm{NG} 1$ $\left(6.6^{\circ} \mathrm{C}\right)=\operatorname{NG} 1\left(6.4^{\circ} \mathrm{C}\right)=\operatorname{sNF}\left(6.0^{\circ} \mathrm{C}\right)$ at 5 and 40 $\mathrm{cm}$ depth, respectively. 


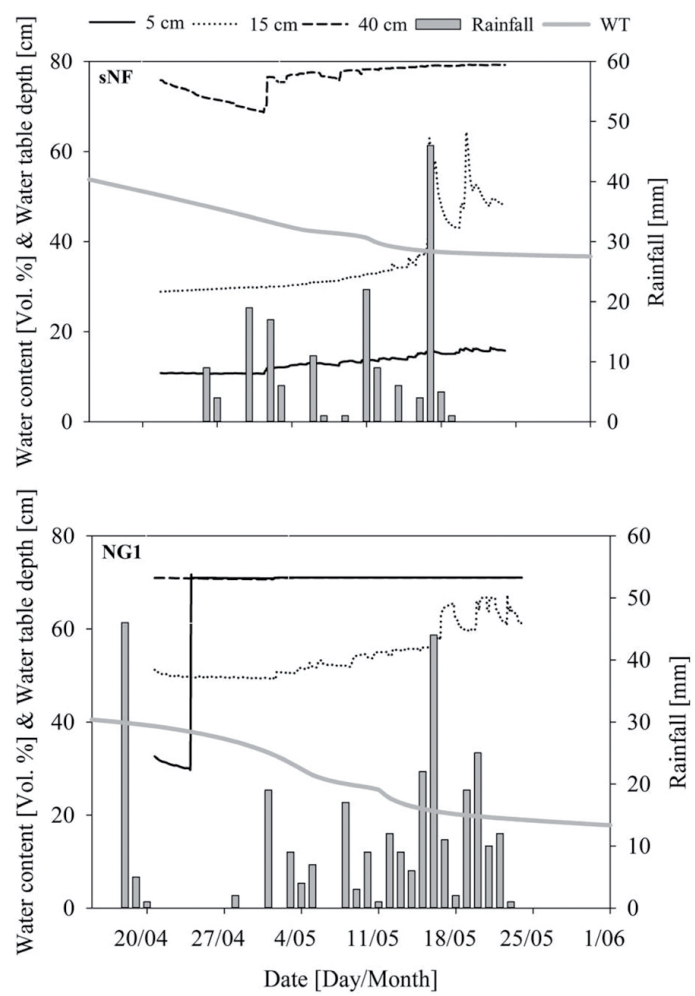

Figure 7. Soil response after intensive drying during summer 2015 for the soil under secondary native forest (sNF) and naturalized grassland (NG1).

\section{Discussion}

Effect of the land use change on time and space dependent physical properties and processes in Aquands

The land use change is a practice used to acquire lands for crop cultivations and pastures, which have existed since the beginning of agriculture (Fuentes and Hajek, 1979). Investigations on their influence on soil physical functions are not new and have been investigated by many scientists (e.g. Ellies et al., 1996; Indorante et al., 2013). However, the impact of the land use change on time and space dependent physical properties and processes is not well known and has to be further researched in order to understand the impact on soil ecosystem services and soil evolution (Dörner et al., 2016). This is particularly relevant in Nadi soils because of their shallow soil depth (Figure 1) and high total porosity (Table 1), which can be strongly modified when the soil is subjected to stresses (e.g. machinery load) greater than its mechanical strength (Horn et al., 1994). In these terms, Haller et al.,(2015) and Dörner et al.,(2016) concluded that after the land use change of a Nadi soil (from sNF to NG) the increase i mechanical strength was related to an increase in bulk density and to a decrease in air capacity (macroporosity), which results in a change in the water/air relationship. The measured dynamics of field water content and temperature verifies these soil deformation effects. The land use change dependent increase in bulk density is also reflected in the water retention curve (Figure 2). The multimodal character observed for Andisols implies the presence of 2 or more inflection points, which reflect well-defined inter- and intra-aggregate porosities. Dörner et al.,(2010 and 2015) and Rudiyanto et al.,(2013) also confirmed the generation of such stepwise patterns of the retention curves due to the downsizing of coarse pores and the formation of finer pores to some extent. Furthermore, Dörner et al.,(2016) not only assessed that the land use change of the Nadi soils affects mainly the inter-aggregate porosity so that a decrease in the macropore volume is registered, but they also proved that it affects the movement of water under saturated conditions, also observed for our study (Table 1). The same has been detected in different soil types (e.g. in Boorman and Klassen, 2008; Tobon et al., 2010) and is related to the susceptibility of macropores to external stresses as also discussed for other Andisols (Dec et al., 2012; Dörner et al., 2010).

The soil deformation induced by mechanical stresses provoked changes in pore size distribution, which, along with pore-continuity, affects the unsaturated hydraulic conductivity, so that $\mathrm{Ku}$ in NF was lower than in NG (Figure 3). 
The depth of the water table depends on dynamics of rainfall and evapotranspiration (e.g. Kutilek and Nielsen, 1994). At the same time, the magnitude of the observed values reflects the depth of the soil profile as affected by the land use and cover change. It is well known that a deeper water table depth corresponds to a deeper soil profile. Consequently our findings confirm these relationships, as the shallower soil profiles were almost completely saturated in June and the dynamics of WT also influenced field water content; the air-filled pores increase rapidly if not enough rainwater is available while the temperature dynamics (Figure 6) show greater temperature gradient. The presented results (Figure 5,6 and 7) consequently provide excellent information about field water content dynamics in the soil profile under the investigated land uses, and these records give more site-specific information. Therefore, in order to understand water content dynamics not only on a temporal, but also on a spatial scale, Dörner et al., (2016) presented the WT dynamics for two contrasting seasons for the same study site. They showed that WT is clearly affected by the soil depth, showing the impact of the land use change on soil depth as well. In these terms, it was observed that while in June the soil under NG was in some parts complete or near saturated, the same was not true in the soil under sNF. This reflects contrasting air/water relationships across the field and also explains the vegetation biodiversity of the specific ecosystems (Ramírez and San Martín, 1993).

The investigated soil is able to store a lot of water due to the high volume of pores (Table 1, Figure 2), which is, however, limited by the shallow soil depth (Figure 1). This implies that during the intensive drying cycle between December 2014 and March 2015 the reduction of $\theta_{\text {Field }}$ exceeded the permanent wilting point at $15 \mathrm{~cm}$ depth (Figure 6 and 7). These changes in water content $\left(\theta_{\text {Field }}\right)$ occur as a natural phenomenon of soil response on the climatic conditions, and depend on the magni- tude of water supply (Figure 5,6), which was clear to see in the soil profile (Figure 7). In these terms, the $\theta_{\text {Field }}$ can vary very quickly during wetting-drying cycles within the whole profile, but the same does not hold true in drying-wetting cycles. In these terms, an inhomogeneous soil wetting and water infiltration was assessed (Figure 7) which can be related to: i) high values of water repellency (Table 1: contact angles $>90^{\circ}$ indicate low wettability according to Yuan and Lee, 2013) under dry conditions (Figure 4), which affects the infiltration after rainfalls and capillarity from the water table, ii) the decrease in hydraulic conductivity from saturated to unsaturated conditions (Figure 3 ) and iii) the effect of land cover on rainfall interception in SNF (Figure 5).

As a consequence of water evaporation, and consequently the energy needed for this purpose, the direction of the soil temperature variations is opposite to those of rainfall and volumetric water content (Figure 5 and 6). Since the soil under the naturalized grassland is directly exposed to solar radiation, the temperature amplitude $\left(\mathrm{A}=\left(\mathrm{T}_{\max }-\mathrm{T}_{\min }\right) / 2\right)$ is higher in NG (values ranged between 5.8 and $0.1^{\circ} \mathrm{C}$ ) compared to sNF (values ranged between 2.7 and $0.1^{\circ} \mathrm{C}$ ). Under saturated conditions at $5 \mathrm{~cm}$ depth, the temperature amplitud reached similar values among land uses $\left(0.1^{\circ} \mathrm{C}\right)$ and the major differences were observed during summer (e.g. on 26.01.2014 NG2 $\left[3.6^{\circ} \mathrm{C}\right]>\mathrm{NG} 1$ $\left.\left[2.7^{\circ} \mathrm{C}\right]>\operatorname{sNF}\left[1.4^{\circ} \mathrm{C}\right]\right)$, highlighting the role of land cover and the air/water relationship in thermal diffusivity (Scheffer-Schachtschabel, 2013). As expected, the temperature $(\mathrm{T})$ decreased with increasing soil depth reducing its amplitude, as well as affecting the extreme values more than the yearly mean. The latter was true for both land uses; however, whereas under water saturated conditions $T$ was almost the same for sNF, NG1 and NG2, as soon as the temperatures started to increase, higher values of $\mathrm{T}$ were assessed in the naturalized grasslands compared to SNF. 
The latter is relevant and shows the impact of the land use and cover changes on physical functioning, but at the same time, indicates that $\mathrm{T}$ dependent processes (e.g. Greenhouse Gas Emissions, organic carbon oxidation) may be affected, and therefore an evolution in the soil behavior can be expected.

\section{Conclusions}

The high total porosity allows the soil to store high levels of water, however, the shallow depth limits this storage capacity, which is further reduced by the mechanical and hydraulic stresses induced by the land use change. Soil structural changes, which occurred mainly in the first $15 \mathrm{~cm}$, reduced the amount of macropores in the soil under naturalized grassland affecting the saturated hydraulic conductivity.

The spatial variability of soil depth caused space dependent water saturation levels as a function of the water table depth; i.e. while the WT in winter reached the soil surface under the naturalized grassland, a fraction of air was available in the soil under native forest due to the deeper water table depth and higher levels of macropore volume and saturated hydraulic conductivity.

The changes in field volumetric water content can change very quickly from saturated to unsaturated conditions for the whole profile, but the same does not hold true in drying-wetting cycles. This reflects an inhomogeneous soil wetting and water infiltration, which can be related to the high values of water repellency, the decrease in hydraulic conductivity from saturated to unsaturated conditions and the effect of land cover on rainfall interception in SNF.

Finally, the land use and cover changes not only impact the water content dynamics and spatial variability, but also the soil thermal behavior. During winter, under saturated conditions the temperature amplitude at $5 \mathrm{~cm}$ depth reached similar values among land uses whereas the major differences were observed during summer, highlighting the role of land cover and the air/water relationships on soil thermal properties. Therefore, the land use change affected the soil physical behavior in the short term, which has to be further researched due to its impact on soil evolution.

\section{Acknowledgements}

We are pleased to thank the Fondecyt grant 1130546 for funding the research project. We are also grateful for the fieldwork conducted by researchers and students of the "Ñadi Soils Team" and the hospitality of the landowners (Don Alfredo and Sra Elba). Finally, Dr. José Dörner also thanks the Alexander von Humboldt Foundation for the Grant "Georg Foster Fellowship for Experienced Researchers" which allows a research stay in the Christian Albrechts University zu Kiel.

\section{References}

Besoain, E., Sepulveda, G., 1985. Minerales secundarios. In: Tosso (Eds.), Suelos Volcánicos de Chile. INIA, Santiago, Chile, pp. 153-214.

CIREN. 2003. Estudio Agrológico X Región. Descripciones de suelos, materiales y símbolos. Publicación 123. Santiago, Chile. 374 p.

Cuevas, J.G., Huertas, J., Leiva, C., Paulino, L., Dörner, J., Arumí, J.L. 2014. Nutrient retention in a microcatchment with low levels of anthropogenic pollution. Bosque. 35(1), 75-88.

Dec, D., Dörner, J., Balocchi, O., Lopez, I. 2012. Temporal dynamics of hydraulic and mechanical properties of an Andisol under grazing. Soil Till. Res. 125, 44-51.

Donoso, C., Lara, A. 1996. Utilización de los bosques nativos en Chile: pasado, presente y futuro. En: Armesto JJ, C Villagrán \& MK Arroyo (eds) 
Ecología de los bosques nativos de Chile: 363-387. Editorial Universitaria, Santiago, Chile.

Dörner, J., Dec, D., Peng, X., Horn, R. 2010. Effect of land use change on the dynamic behaviour of structural properties of an Andisol in southern Chile under saturated and unsaturated hydraulic conditions. Geoderma. 159, 189-197.

Dörner, J., Huertas, J., Cuevas, J.G., Leiva, C., Paulino, L., Arumí, J.L. 2015. Water content dynamics in a volcanic ash soil slope in southern Chile. J. Plant Nutr. Soil Sci. 178, 693-702.

Dörner, J., Dec, D., Thiers, O., Paulino, L. Zúniga, F., Valle, S., Martínez, O., Horn, R. 2016. Spatial and temporal variability of physical properties of Aquands under different land uses in southern Chile. Soil Use and Management. 32: 411-421.

Ellies, A., Smith, R., Horn, R. 1996. Transmisiones de presiones en el perfil de algunos suelos. Agro Sur. 24, 149-158.

Ellies, A. 2001. Cambio de las propiedades físicas del suelo con el drenaje. p. 66-72, Boletín $\mathrm{N}^{\circ} 17$, Sociedad Chilena de la Ciencia del Suelo.

Ellies, A., Ramírez, C., Mac Donald, R. 2003. Wetting capacity in aggregates from soils with a different management. Food, Agr. Env. 1, 229-233.

Fuentes, E.R., Hajek, E.R. 1979. Patterns of landscape modification in relation to agricultural practice in central Chile. Environ. Conservation. 6, 265-271.

Gerding, V., Thiers, O., Schlatter, J. \& Sanzana, J. 2014. Suelos ñadi para una producción forestal sostenible: principales problemas, causas y propuestas de solución. Revista Bosque Nativo. 53, 36-43.

Haller, P., Dec, D., Zúñiga, F., Ivelic, J., Dörner, J. 2015. Effect of hydraulic and mechanical stresses on the functional resistance and resilience of the porous system of a ñadi (Aquands) under different land uses. Agro Sur. 43(2), 41-52.
Hallett, P.D., Nunan, N., Douglas, J.T., Young, I. M. 2004. Milimeter-scale spatial variability in soil water sorptivity: scale, surface elevation, and subcritical repellency effects. Soil Sci. Soc. Am. J. 68, 352-358.

Horn, R., Taubner, H., Wuttke, M., Baumgartl, T.1994. Soil physical properties related to soil structure. Soil Till. Res. 30, 187-216.

Indorante, S., Kabrick, J., lee, B., Maata, J. 2013. Quantifying Soil Profile Change Caused by Land Use in Central Missouri Loess Hillslopes. Soil Sci. Soc. Am. J. 78, 225-237.

IPCC. 2013. Climate Change 2013: The Physical Science Basis. IPCC Working Group I Contribution to AR5, Switzerland.

Klute, A. 1986. Methods of Soil Analysis. Part 1: Physical and Mineralogical Methods, 2nd ed. SSSA, Madison, WI (SSSA Book Ser. 5).

Kutílek, M., Nielsen, D. 1994. Soil Hydrology. GeoEcology Textbook. Catena Verlag, Cremlingen, Germany.

Novoa R, Villaseca R. 1989. Mapa Agroclimático de Chile. Instituto de Investigaciones Agropecuarias (INIA), Ministerio de Agricultura, Santiago, Chile. 221 pp.

Ramírez, C., San Martín, C. 1993. La transformación antrópica de la vegetación de los Ñadi de área Mapuche en el centro-sur de Chile. Boletín Museo Regional de la Araucanía. 4(1), 205-214.

Richter, D., Markewitz, D., 1995. How deep is soil? BioScience. 45, 600-609.

Rudiyanto, N., Toride, M., Sakai, M., van Genuchten, M. 2013. Estimating the unsaturated hydraulic conductivity of Andisols using the evaporation method. J. Jpn. Soc. Soil Phys. 125: 3-15.

Scheffer, F., Schachtschabel, P. 2010. Lehrbuch der Bodenkunde, 16. Auflage. Blume, H.-P., Brümmer, G.W., Horn, R., Kandeler, E., Kögel-Knabner, I., 
Kretzschmar, R., Stahr, K., Wilke, B.-M. (Eds.), Spektrum Akademischer Verlag, Heidelberg, Germany.

Schindler , U., Durner, W., von Unold, G., Mueller, M., Wieland, R. 2010. The evaporation method: Extending the measurement range of soil hydraulic properties using the air-entry pressure of the ceramic cup. J. Plant Nutr. Soil Sci. 173, 563-572.

Thiers O., Gerding, V., Lara, A. \& Echeverría, C. 2007. Variación de la napa freática en un suelo ñadi bajo diferentes tipos vegetacionales, X Región, Chile. In: Libro de actas de Eco Reuniones. Primera reunión sobre forestación en la patagonia EcoForestar 2007. CIEFAP, Argentina. 259-266.
Tobón, C., Bruijnzeel, L., Frumau, K., Calvo-Alvarado, J. (2010): Changes in Soil Physical Properties after Conversion of Tropical Montane Cloud Forest to Pasture in Northern Costa Rica, in Bruijnzeel, L. A., Scatena, F. N., Hamilton, L. S. (eds.): Tropical Montane Cloud Forests: Science for Conservation and Management. Cambridge University Press, Cambridge, UK, pp. 502-515.

Van Genuchten, M., Simunek, J., Leij, J., Sejna, M. 2009. Code for quatifying the hydraulic functions of unsaturated soils. RETc v. 6.02 .

Wilson, K., Newton, A., Echeverría, C.,Weston, C., Burgman, M. 2005. A vulnerability analysis of the temperate forest of south central Chile. Biol. Conserv. $122,9-21$. 